\title{
QUALITY OF LIFE, PHYSICAL CONDITIONING AND ANTHROPOMETRIC INDICES OF MILITARY PERSONNEL FROM THE CENTRAL DA AERONÁUTICA (HCA-RJ)
}

\section{CALIDAD DE VIDA, CONDICIONAMENTO FISICO E INDICES ANTROPOMETRICOS DE MILITARES DEL HOSPITAL CENTRAL DE LA AERONAUTICA (HCA-RJ).}

\author{
Fortes de Sá Rego, Marcos ${ }^{1}$; de Mello Braga, Danielli ${ }^{2}$, Martinez Camillo, Eduardo ${ }^{1}$ Cotian, Michela ${ }^{1} \&$ Marson \\ Augusto, Runer ${ }^{1}$
}

\begin{abstract}
${ }^{1}$ Brazilian Army Research Institute of Physical Fitness (Instituto de Pesquisa da Capacitação Física do Exército - IPCFEx $-\mathrm{RJ})$

${ }^{2}$ Brazilian Army Physical Education School (Escola de Educação Física do Exército - EsEFEx - RJ)
\end{abstract}

FORTES D.S.R.M; DE MELLO B.D.; MARTINEZ C.E.; COTIAN M. \& MARSON A.R. Quality of life, physical conditioning and anthropometric indices of military personnel from the Central da Aeronáutica (HCA-RJ). Mot. Hum. 14(2): 59-67.

\section{ABSTRACT}

This article presents the nutritional profile, namely the body mass (BM), stature, body mass index (BMI) and waist circumference (WC), based on the Fitness and Physical Conditioning Test (APFT), and the quality of life of 527 active-duty military personnel of both genders from the Brazilian Air Force Central Hospital. Quality of life was assessed using the WHOQOL-bref. The data analysis was performed with STATISTICA software version 7.0. For the statistical analysis, parametric tests were used as a function of the normal distribution of the data. Student's t-test for unpaired samples was used to compare the two groups (female (FG) and male (MG)). The Pearson correlation was used to evaluate the degree of association between the anthropometric measurements and the results from the physical tests. $P$ values $<0.01$ were considered significant. The MG showed a significant difference in BM, stature, BMI and WC compared with the FG but did not differ with respect to age. Regarding the APFT, the MG showed a significant difference in the physical tests compared with the FG. On the quality of life questionnaire, there was no significant difference in any of the domains of the WHOQOL-bref assessment. Applying the Pearson partial correlation coefficient (controlled for gender) showed that WC and BMI showed a weak to moderate significant correlation with the results of the APFT.

Key words: Anthropometric meassurements, physical test, military personnel

\section{RESUMEN}

En este artículo se presenta el perfil nutricional, es decir, la masa corporal ( MC), estatura, índice de masa corporal (IMC) y la circunferencia de la cintura (CC), basado en la prueba de aptitud y acondicionamiento físico ( APAFT ), y la calidad de vida de 527 activos resistencia militares de ambos sexos de la brasileña Air hospital Central de la Fuerza. Se evaluó la calidad de vida mediante el WHOQOL -BREF. El análisis de los datos se realizó con el programa Statistica versión 7.0. Para el análisis estadístico , pruebas paramétricas se utilizaron como una función de la distribución normal de los datos. Prueba de la t de Student para muestras independientes se utilizó para comparar los dos grupos ( mujeres $(G M)$ y hombres $(G H)$ ). La correlación de Pearson se utilizó para evaluar el grado de asociación entre las mediciones antropométricas y los resultados de las pruebas físicas. Los valores de $p<0,01$ fueron considerados significativos. La GH mostró una diferencia significativa en el MC, estatura, IMC y la CC en comparación con el GM, pero no fue diferente con respecto a la edad. En cuanto a la APAFT , la GH mostró una diferencia significativa en las pruebas físicas en comparación con la de GM. En el cuestionario de calidad de vida, no hubo ninguna diferencia significativa en ninguno de los dominios de la evaluación de WHOQOL - BREF. Aplicando el coeficiente de correlación parcial de Pearson ( controlados por género ) mostró que la CC y el IMC mostraron una débil a moderada correlación significativa con los resultados de la APAFT.

Palabras clave: Medidas Antropométricas, test físicos, personal militar 


\section{INTRODUCTION}

Over the last five decades, demographic, epidemiological, nutritional and technological changes have transformed the lives of people in a manner never before seen or imagined. These changes have both pros and cons in terms of wellbeing and quality of life (QOL). Approximately three decades ago, the causes and consequences of population growth were discussed; currently, the causes underlying this demographic transition are being discussed. Impressive population growth, an increase in life expectancy and the large concentration of population in urban areas have raised important questions related to lifestyle, with respect to both public health and leisure policies and the sustainability of the planet. Regarding this last aspect, we are witnessing discussions on global warming, which has been caused essentially by the individual and collective lifestyles of contemporary industrialized societies. (Brito, 2008; Nahas \& Garcia, 2010)

Conceptualizing QOL is not an easy task due to its subjective character, complexity and various dimensions. The QOL of an individual depends on intrinsic and extrinsic factors that vary from person to person and are subject to the influences of his/her daily routine, the locale where he/she lives and his/her habits and lifestyle (Rugiski, Pilatti, \& Scandelari, 2005). According to Gordia et al. (2011), the term "quality of life" has been heavily used in recent decades by the media, in academics and in daily conversations due to the growing individual and collective concern with the health and well-being of the population. (Kluthcovsky \& Takayanagui, 2010)

The absence of a tool that could evaluate QOL from an international perspective led the World Health Organization (WHO) to form a Quality of Life Group (WHOQOL Group) with the objective of developing tools that have a transcultural perspective. A questionnaire composed of 100 items, the WHOQOL-100 (Fleck, 2000), resulted from this collaborative, multicenter project.

The need for rapid application tools led the WHOQOL Group to develop an abbreviated version of the WHOQOL-100, termed the WHOQOL-bref. This tool consists of 26 questions divided into four domains: physical, psychological, social relationships and environmental (Fleck et al., 2000; Kluthcovsky \& Kluthcovsky, 2009).

The increase in the global load of chronic non-communicable diseases (CNCDs) is a global public health problem. In this context, physical activity is emphasized as a way to promote health and prevent these diseases (Bicalho et al., 2010). CNCDs have multifactorial etiologies and share various modifiable risk factors such as tobacco use, physical inactivity, inappropriate nutrition, obesity, dyslipidemia and alcohol consumption (Chor \& Menezes, 2011; Freitas \& Garcia, 2012; Malta et al., 2012).

For this purpose, the WHO launched the Global Strategy on Healthy Diet, Physical Activity and Health (GS/WHO) because a healthy diet and lifestyle constitute strategies that can diminish the occurrence and severity of CNCDs (Costa et al., 2009). In Brazil, the federal government, through the Brazilian Health Ministry, launched a strategic action plan to confront CNCDs from 2011-2022 (Malta et al., 2010).

Physical inactivity is a public health challenge that must be combated to prevent obesity and thus improve health and well-being. For substantial health benefits, current guidelines recommend that adults practice at least 2.5 hours of moderate intensity or 1.25 hours of vigorous intensity aerobic physical activity per week. Additionally, moderate- or high-intensity musclestrengthening activities are recommended for all main muscle groups and should be performed two or more days per week for additional health benefits (Hakkinen et al., 2010).

Regular physical exercise is associated with a decrease in the incidence of cardiovascular events; a decrease in arterial pressure (Brum et al., 2004; Nunes et al., 2006); and improvements in body weight, insulin sensitivity (Pauli et al, 2009; Meex et al., 2010) and inflammatory variables (Ristow et al., 2009; Teodoro et al., 2010).

The WHO recommends the use of anthropometrics to monitor risk factors for chronic diseases (Ristow et al, 2009). In epidemiological studies of overweight and obese individuals, clinical evaluations have commonly been 
performed through anthropometric measurements of body mass and stature or a combination of these two measurements; these measurements have the benefits of being practical, low cost and easy to interpret (Rech et al., 2006).

In addition to body mass index (BMI) and waist circumference (WC), the waist-hip ratio (WHR) is capable of accurately detecting individuals with an excess of weight and other cardiovascular risk factors (Han et al., 1995; Lean et al., 1995). Some authors consider WC to be a better predictor of metabolic risk factors than WHR and BMI (Janssen, 2010; Leitzmann et al., 2011). WC increase is considered to be an independent risk factor for morbidity/mortality caused by CNCDs (da Silva Linhares et al., 2012; Klein et al., 2012; Wei et al., 2012; Zhu et al., 2012).

Every member of the Brazilian Air force must perform the Army Physical Fitness Test (APFT) twice a year; these results classify the individuals with regards to physical fitness. The APFT involves the evaluation of various components, such as body mass, stature, measurement of circumferences, body composition, a 12-minute run $\left(\mathrm{VO}_{2 \max }\right)$, flexion and extension of the upper extremities (FEUE) and flexion of the torso over the thighs (FTOT).

The present study consists of a retrospective analysis of a subset of military personnel from the Brazilian Air Force Central Hospital. The main objective of this study is to diagnose and analyze indicators of QOL, level of physical conditioning and the anthropometric indices of the employees of the Brazilian Air Force Central Hospital.

\section{MATERIALS AND METHODS}

The study population comprised 527 active military personnel of both genders from the Brazilian Air Force Central Hospital. This population underwent the APFT, and its results were collected. From these results, the anthropometric indices were assessed. QOL was assessed through the WHOQOL-bref.

To characterize and verify the homogeneity of the sample, anthropometric measurements were collected for body mass, stature and the calculation of the BMI using a digital scale with a precision of $100 \mathrm{~g}$ (FILIZOLA, model PL150 Personal Line Brazil), a professional SANNY stadiometer (Brazil) and a LANGE skinfold caliper (USA) with $1 \mathrm{~mm}$ of precision and constant pressure of $10 \mathrm{~g} / \mathrm{mm}^{2}$, respectively. All collection points were as prescribed by the International Standards for Anthropometric Assessment (ISAK) (MarfellJones et al., 2006).

The Portuguese version of the WHOQOLbref was used to evaluate QOL. This tool contains 26 questions distributed in four domains: social relationships, psychological, physical and environmental. Each domain consists of questions with scores that vary from 1 to 5 .

\section{Relationship of the Physical Tests FEUE Test - Flexion and extension of the upper extremities}

Duration: No time limit.

Attempts: Two.

Initial position: Front support with the palms of the hands on the ground, slightly separated relative to the shoulders, with the body fully extended.

1st Period: Bend the arms to bring the chest as close as possible to the ground, so the back passes the line of the elbows, keeping the body extended and the elbows projected outward at approximately $45^{\circ}$ in relation to the torso.

2nd Period: Extend the arms, returning to the initial position.

Counting: One repetition was counted when the extension was completed.

No. of repetitions: The maximum number of repetitions, without pauses for rest and without mischaracterizing the exercise. The APFT evaluator could interrupt the test when the candidate had reached the minimum effort number stipulated for his/her age range.

Observations:

a) Women supported their knees on the ground for this exercise. The APFT evaluator could interrupt the test when the candidate had reached the minimum effort number stipulated for his/her age range;

b) To keep the elbows projected outwards, the evaluated individual could adduce his/her hands in the initial position. 


\section{Test FTOT - Flexion of the torso over the thighs}

Observations: In this exercise, the same standards of execution were required for both genders.

Duration: One minute.

Attempts: Two.

Initial position: Lying supine, with hands crossed over the chest at the height of the shoulders, knees at a $90^{\circ}$ angle, feet aligned with the extension of the hips and firmly positioned on the ground with the help of the evaluator (seeking to maintain the thighs and the knees free).

Only Period: Bend the torso until the elbows touch the distal third of the thighs.

Counting: One repetition was counted when the subject returned to the initial position and the scapulas touched the ground.

Time: A single repetition was counted each time the period was completed.

No. of repetitions: The maximum number of correct repetitions that the individual was able to perform in 1 minute. The APFT evaluator could interrupt the test when the candidate had reached the minimum effort number stipulated for his/her age range.

\section{Twelve-minute run or march}

Duration: 12 minutes.

Attempts: One.

Time and distance: The evaluator informed the candidate of the number of laps covered and the time elapsed during this test, from its beginning until the ninth minute. After the ninth minute, the evaluator would only report to the candidate the laps covered but not the elapsed time.

Whistle: The test was initiated with a short blow from a whistle and terminated with a long blow. At this time, the evaluated individuals began their cool down, walking in a direction perpendicular to the track until the instructor had made note of the distance run by them and released them from the test.
Numbering: All of the candidates received numbers to facilitate control by the evaluator.

Location: An athletics track or any other flat course, preferably with 500/100 meters, with a slope less than 1/1000 and duly measured. The track could be of any type as long as it was the same during the entire race. Whenever possible, intermediate markings were made to facilitate the evaluated individuals in maintaining their pace.

Execution: The 12-minute run could be performed at any conditioned pace, mixing running with walking, as long as the alternation corresponded to his/her maximum effort for the allotted time. The individual was not allowed to stop or sit to rest.

Counting: The result obtained was a function of the distance covered by the evaluated individual during the established time. To control for the laps run by each candidate, the evaluator used the "Record of control of laps for the 12-minute run or march test" and rounded the distance obtained to the nearest 10 meters.

The formula for calculating $\mathrm{VO}_{2} \max$ is as follows:

$\mathrm{VO}_{2} \max =($ Dist. covered (meters) - 504.9) / $44.73=\mathrm{VO}_{2}$ in $\mathrm{ml} /(\mathrm{kg} \cdot \mathrm{min})$

\section{Statistical Analysis}

The data analysis was performed using the STATISTICA software version 7.0. For the statistical analysis, parametric tests were used as a function of the normal distribution of the data. Therefore, to compare the two groups (female (FG) and male (MG)), Student's $t$-test for unpaired samples was used. The Pearson correlation was used to evaluate the degree of association between the anthropometric measurements and the results from the physical tests. $\mathrm{P}$ values $<0.01$ were considered significant.

\section{RESULTS}

Table 1: Results of the Student's $t$-test for the body composition of officers of both genders from the Brazilian Air Force (women $=235$; men $=292$; total $=527$ ).

\begin{tabular}{lcccc}
\hline & Female Average (FG) & Male Average (MG) & t-value & $\boldsymbol{p}$ \\
\hline AGE (Years) & $32.3 \pm 6.3$ & $31.2 \pm 8.9$ & 1.6488 & 0.099785 \\
BODY MASS (Kg) & $63.4 \pm 9.3$ & $79.9 \pm 13.7$ & -15.7980 & $\mathbf{0 . 0 0 0 0 0 0 *}$ \\
STATURE $(\mathbf{c m})$ & $163.1 \pm 5.7$ & $175.7 \pm 7.0$ & -22.4406 & $\mathbf{0 . 0 0 0 0 0 0}$ \\
WAIST CIRCUMFERENCE $(\mathbf{c m})$ & $74.5 \pm 7.8$ & $85.5 \pm 10.0$ & -13.9716 & $\mathbf{0 . 0 0 0 0 0 0}$ \\
BMI & $23.8 \pm 3.2$ & $25.8 \pm 3.7$ & -6.5142 & $\mathbf{0 . 0 0 0 0 0 0 *}$ \\
\hline
\end{tabular}

$* p<\mathbf{0 . 0 1}$ 
In Table 1, the MG showed a significant

difference in body mass, stature, BMI and WC in relation to the FG but did not differ with respect to age.

Table 2: Results of the Student's $t$-test regarding the physical tests applied to officers of the Brazilian Air Force (women $=235$; men $=292$; total $=527$ ).

$* p<0.01$

\begin{tabular}{llll}
\multicolumn{4}{l}{ men $=292$; total $=527)}$. \\
Physical Test & $\begin{array}{l}\text { Female } \\
\text { Average }(\text { FG })\end{array}$ & $\begin{array}{l}\text { Male Average } \\
(\text { MG) }\end{array}$ & $\boldsymbol{P}$ \\
\hline FEUE & $25.3 \pm 7.7$ & $28.9 \pm 10.4$ & $\mathbf{0 . 0 0 0 0 0 8 *}$ \\
FTOT & $26.9 \pm 9.9$ & $35.6 \pm 10.7$ & $\mathbf{0 . 0 0 0 0 0 0} *$ \\
VO $_{2 \max }(\mathbf{m l} / \mathbf{k g} / \mathbf{m i n})$ & $27.47 \pm 5.3$ & $36.38 \pm 7.0$ & $\mathbf{0 . 0 0 0 0 0 0} *$ \\
\hline
\end{tabular}

FEUE - Flexion and extension of the upper extremities

FTOT - Flexion of the torso over the thighs

In Table 2, the MG showed a significant difference for all variables related to the physical tests compared with the FG.

Table 3: Results of the Student's $t$-test for the WHOQOL-bref applied to officers of the Brazilian Air Force $($ women $=235$; men $=$ 292 ; total $=527$ ).

\begin{tabular}{llll}
\hline WHOQOL-bref & Female Average & Male Average & $\boldsymbol{P}$ \\
\hline Physical Domain & $12.93 \pm 1.53$ & $12.96 \pm 1.80$ & 0.854873 \\
Psychological Domain & $14.10 \pm 1.61$ & $14.40 \pm 1.85$ & 0.177318 \\
Social Relationships Domain & $16.28 \pm 2.62$ & $16.41 \pm 2.39$ & 0.704862 \\
Environment Domain & $14.03 \pm 2.03$ & $13.78 \pm 2.20$ & 0.334645 \\
\hline
\end{tabular}

$* p<0.01$

In Table 3, regarding the QOL, there was no significant difference for any of the variables based on the WHOQOL-bref.

Table 4: Partial correlation coefficient (controlled by gender) between the scores for the domains and body mass index (BMI), waist circumference (WC), flexion and extension of the upper extremities (FEUE), flexion of the torso over the thighs (FTOT) and cardiorespiratory conditioning $\left(\mathrm{VO}_{2} \mathrm{max}\right)$ in 526 active military personnel of the Brazilian Air Force from the Brazilian Air Force Central Hospital in Rio de Janeiro.

\begin{tabular}{llll}
\hline Partial Correlation & FEUE & FTOT & VO $_{2 \max }$ \\
\hline WC & $-0.37 *$ & $-0.31^{*}$ & $-0.40^{*}$ \\
BMI & $-0.24 *$ & $-0.25 *$ & $-0.39 *$ \\
\hline
\end{tabular}

$* p<0.01$

FEUE - Flexion and extension of the upper extremities

FTOT - Flexion of the torso over the thigh 
In Table 4, the results from the Pearson partial correlation coefficient calculation (controlled by gender) show that the WC and the BMI show a weak to moderate significant correlation with the APFT results.

\section{DISCUSSION}

The study results related to the nutritional profile, namely BM, stature, BMI and WC, show a significant difference between the MG and the FG. These results corroborate other findings when comparing anthropometric variables between men and women (Bigaard et al., 2012; de Carvalho Anselmo et al., 1992; Provencher et al., 2012).

In relation to the physical tests, the results of this study show that the MG was superior with respect to the FG for all three tests performed, even the test of the flexion of the arm (FEUE), where the FG could perform the test with their knees supported on the ground.

According to the Position of the Brazilian Society of Sports Medicine (Sociedade Brasileira de Medicina do Esporte (SBME)) (Leitão et al., 2000), the genders exhibit differences with regards to exercise physiology. Men have greater muscle mass in absolute and relative terms (per total body weight), while women have a higher percentage of body fat, which results in lower thermoregulatory efficiency when exercising in a warm environment. Even though the composition of the muscle fibers is similar in men and women, the volume of each fiber, whether type I or II, is greater in men, thus conferring greater power and muscle endurance to men.

The potential difference in muscular strength between the genders indicates that women show two thirds the strength of men. Frontera et al. (1991) analyzed the isokinetic force of the extensors and flexors of the elbow and knee in 200 healthy individuals (86 males and 114 females) with ages between 45 and 78 . The absolute strength of the females varied from $42.2-62.8 \%$ of the strength of the males.
According to Salvador et al. (2005), these differences may be related to fatigue resistance capacity, muscle mass, predominance of the use of substrates, muscle architecture and the depolarization of the motor units.

Chen et al. (2012) analyzed the difference in muscle strength for 11 exercises with weights in 277 young students of both genders. Muscle strength was significantly greater for males; the females displayed 37-68\% of the force of their male partners. Additionally, the difference was greater in the upper extremities and smaller in the lower extremities.

Regarding $\mathrm{VO}_{2 \max }$, the literature also points to superior results in favor of males. In the present study, the MG obtained a significantly superior result compared to the FG (36.38 \pm 7.0 vs. $27.47 \pm 5.3$, respectively; $p<0.01$ ).

A study performed by Azevedo et al. (2010) analyzed nine sedentary men and nine sedentary women, who were without any physical activity for at least six months, with ages between 20 and 30 years. A significant difference was found for the $\mathrm{VO}_{2 \max }(42.66 \pm 4.50$ vs. $32.92 \pm 6.03 ; p=0.001)$ and the $\mathrm{VO}_{2}$ kinetics during the run at the velocity associated with the $\mathrm{VO}_{2 \max }\left(\mathrm{v} \mathrm{VO}_{2 \max }\right)(13.2 \pm 1.5$ vs. $10.3 \pm 2.0 ; p=0.01)$ between men and women, respectively.

Regarding the results of the WHOQOL-bref assessment, significant differences were not found between the domains. It is worth noting the scarcity of studies that use a sample composed of military personnel.

Calumbi et al. (2010) conducted a study with 110 anesthesiologists from the city of Recife who were $43.2 \pm 11.1$ years old. Most of these anesthesiologists were women, and they showed significantly lower scores than the men in the psychological and social relationship domains of this study. .

In the study by Cieslak et al. (2007), where the subjects were physical education instructors with an average age of $20.74 \pm 2.79$ years, the 
central trend measurements showed a satisfactory QOL for both genders, with the men obtaining better values for the physical domain and the women obtaining better values for the social relationships domain. However, significant differences were not found between the genders for the physical, psychological, environmental and general domains.

Martinez et al. (2009) conducted a study with 130 university professors from the city of Bauru-SP and did not find a significant difference between the genders in any of the domains.

\section{CONCLUSIONS}

The present study consisted of a retrospective analysis of a subset of military personnel from the Brazilian Air Force Central Hospital. The main objective of this study was the diagnosis and analysis of indicators of QOL, the level of physical conditioning and anthropometric indices of employees of the Brazilian Air Force Central Hospital.

In relation to the physical tests, male individuals were superior to their female partners, both in terms of strength and oxygen consumption, which is in agreement with the majority of the studies found in the literature. Regarding the WC and BMI variables, the results showed an inverse and significant correlation, confirming that excess weight significantly influences physical performance.

Regarding body composition, results that are similar to the literature were also found, where males showed significant differences in all the studied variables.

Significant differences were not found between the genders regarding the results from the WHOQOL-bref.

Based on the scarcity of studies addressing QOL in military personnel, we suggest that more investigations should be conducted on this population.

\section{BIBLIOGRAPHYC REFERENCES}

Azevedo, P. H. S. M., Oliveira, J. C., Simões, H. G., Baldissera, V., \& Perez, S. E. A. (2010). Oxygen uptake kinetics and threshold time at the vVO2max: tomparison between men and women. Revista Brasileira de Medicina do Esporte, 16(4), 278-281.

Bicalho et al. (2010). Atividade física e fatores associados em adultos de área rural em Minas Gerais, Brasil. Revista de Saúde Pública, 44(5), 884-893.

Bigaard et al. (2012). Waist Circumference, BMI, Smoking, and Mortality in Middle-Aged Men and Women. Obesity research, 11(7), 895-903.

Brito, F. (2008). Transição demográfica e desigualdades sociais no Brasil. Rev Bras Estud Popul, 25, 5-26.

Brum, P. C., Forjaz, C. L. M., Tinucci, T., \& Negrão, C. E. (2004). Adaptações agudas e crônicas do exercício físico no sistema cardiovascular. Rev Paul Educ Fís, 18, 21-31.

Calumbi, R. A., Amorim, J. A., Maciel, C. M. C., Damázio, O., \& Teles, A. J. F. (2010). Avaliação da qualidade de vida dos anestesiologistas da cidade do Recife. Rev Bras Anestesiol, 60, 42-51.

Chen, G., Liu, L., \& Yu, J. (2012). A Comparative Study on Strength between American College Male and Female Students in Caucasian and Asian Populations. Sport Science Review (3), 153-165.

Chor, D., \& Menezes, P. R. (2011). Saúde no Brasil 4 Doenças crônicas não transmissíveis no Brasil: carga e desafios atuais. Veja, 6736(11), 60135-60139.

Cieslak, F., Levandoski, G., Góes, S. M., Santos, T. K., Junior, G. B. V., \& Leite, N. (2007). Relação do nível de qualidade de vida e atividade física em acadêmicos de educação física. Fitness \& performance journal(6), 357-361.

Costa et al. (2009). Mudança nos parâmetros antropométricos: a influência de um programa de intervenção nutricional e exercício físico em mulheres adultas. Cadernos de Saúde Pública, 25, 1763-1773.

da Silva Linhares, R., Horta, B. L., Gigante, D. P., Dias-daCosta, J. S., \& Olinto, M. T. A. (2012). Distribuição de obesidade geral e abdominal em adultos de uma cidade no Sul do Brasil Distribution of general and abdominal obesity in adults in a city in southern Brazil. Cad. Saúde Pública, 28(3), 438-448.

de Carvalho Anselmo, M. A., Burini, R. C., Angeleli, A. Y. O., da Silva Mota, N. G., \& Campana, Á. O. (1992). Avaliação do estado nutricional de indivíduos adultos sadios de classe média. Ingestão energética e protéica, antropometria, exames bioquímicos do sangue e testes de imunocompetência. 
Paper apresentado para publicação, financiado pela FAPESP. Processo Saúde Coletiva.

Fleck, M. P. A. (2000). O instrumento de avaliação de qualidade de vida da Organização Mundial da Saúde (WHOQOL-100): características e perspectivas. Ciência \&amp; Saúde Coletiva, 5(1), 33-38.

Fleck, M. P. A., Louzada, S., Xavier, M., Chachamovich, E., Vieira, G., Santos, L., \& Pinzon, V. (2000). Aplicação da versão em português do instrumento abreviado de avaliação da qualidade de vida" WHOQOL-bref. Rev saúde pública, 34(2), 178-183.

Freitas, L. R. S., \& Garcia, L. P. (2012). Evolução da prevalência do diabetes e deste associado à hipertensão arterial no Brasil: análise da Pesquisa Nacional por Amostra de Domicílios, 1998, 2003 e 2008. Epidemiologia e Serviços de Saúde, 21(1), 07-19.

Frontera, W R., Hughes, V. A., Lutz, K. J., \& Evans, W. J. (1991). A cross-sectional study of muscle strength and mass in 45-to 78-yr-old men and women. Journal of Applied Physiology, 71(2), 644-650.

Gordia, A. P., de Quadros, T. M. B., de Oliveira, M. T. C., \& de Campos, W. (2011). Qualidade de vida: contexto histórico, definição, avaliação e fatores associados-DOI: 10.3895/S2175-08582011000100005. Revista Brasileira de Qualidade de Vida, 3(1).

Hakkinen et al. (2010). Health and Quality of Life Outcomes. Health and Quality of Life Outcomes, 8, 15.

Han, T., Van Leer, E., Seidell, J., \& Lean, M. (1995). Waist circumference action levels in the identification of cardiovascular risk factors: prevalence study in a random sample. Bmj, 311(7017), 1401.

Klein et al. (2012). Waist circumference and cardiometabolic risk: a consensus statement from shaping America's health: Association for Weight Management and Obesity Prevention; NAASO, the Obesity Society; the American Society for Nutrition; and the American Diabetes Association. Obesity, 15(5), 1061-1067.

Kluthcovsky, A., \& Kluthcovsky, F. (2009). WHOQOL-bref, um instrumento para avaliar qualidade de vida: uma revisão sistemática. Rev Psiquiatr Rio Gd Sul, 31(3).

Kluthcovsky, A. C. G. C., \& Takayanagui, A. M. M. (2010). Qualidade de Vida-Aspectos Conceituais. Revista Salus, 1(1).

Lean, M., Han, T., \& Morrison, C. (1995). Waist circumference as a measure for indicating need for weight management. Bmj, 311(6998), 158.

Leitão et al. (2000). Posicionamento oficial da Sociedade Brasileira de Medicina do Esporte: atividade física e saúde na mulher. Revista brasileira de medicina do esporte, 6(6), 215220.

Malta, D.C., O.L. Morais Neto, \& Silva Junior, J.B. (2011) Apresentação do plano de ações estratégicas para o enfrentamento das doenças crônicas não transmissíveis no Brasil, 2011 a 2022. Epidemiologia e Serviços de Saúde,. 20(4), 425-438.

Malta et al. (2012). Monitoring of Risk and Protective factors for Chronic Non Communicable Diseases by telephone survey in Brazilian State Capitals, 2008. Revista Brasileira de Epidemiologia, 15(3), 639-650.

Marfell-Jones, T., Stewart, A., \& Carter, L. (2006). International standards for anthropometric assessment. South Africa: International Society for the Advancement of Kinanthropometry.

Martinez, K., Vitta, A., \& Lopes, E. S. (2009). Avaliação da qualidade de vida dos professores universitários da Cidade de Bauru-SP. Salusvita, 28, 217-224.

Meex et al. (2010). Restoration of muscle mitochondrial function and metabolic flexibility in type 2 diabetes by exercise training is paralleled by increased myocellular fat storage and improved insulin sensitivity. Diabetes, 59(3), 572.

Nahas, M. V. \& Garcia, L. M. T. (2010). Um pouco de história, desenvolvimentos recentes e perspectivas para a pesquisa em atividade física e saúde no Brasil. Rev. bras. Educ. Fís. Esp, 24(1).

Nunes, A., Rios, A. C. S., Cunha, G. A., Barretto, A. C. P., Negrão, C. E. (2006). Efeitos de um programa de exercício físico não supervisionado e acompanhado a distância, via Internet, sobre a pressão arterial e composição corporal em indivíduos normotensos e pré-hipertensos. Arq Bras Cardiol, 86(4), 289-296.

Pauli, J. R., Cintra, D. E., Souza, C., Ropelle, E. R. (2009). Novos mecanismos pelos quais o exercício físico melhora a resistência à insulina no músculo esquelético. Arq. Bras. Endocrinol. Metab, 53, 399-408.

Provencher, V., Drapeau, V., Tremblay, A., Després, J. P., \& Lemieux, S. (2012). Eating behaviors and indexes of body composition in men and women from the Quebec family study. Obesity research, 11(6), 783-792.

Rech, C. R., Petroski, E. L., Silva, R. C. R., \& Silva, J. C. N. (2006). Indicadores antropométricos de excesso de gordura corporal em mulheres. Revista Brasileira de Medicina do Esporte, 12(3), 119-124.

Ristow et al. (2009). Antioxidants prevent health-promoting effects of physical exercise in humans. Proceedings of the National Academy of Sciences, 106(21), 8665. 
Rugiski, M., Pilatti, L. A., \& Scandelari, L. (2005). WHOQOL-100 e sua utilização: uma pesquisa na Internet. PILATTI, AL; KOVALESKI, JL; OLIVERIA, SL Temas em Engenharia de Produção I. Jundiaí: Fontoura, 21-30.

Salvador et al. (2005). A comparison of motor performance between men and women in multiple series of weight exercises. Revista brasileira de medicina do esporte, 11(5), 257-261.

Teodoro, B. G., Natali, A. J., Fernandes, S. A. T., Peluzio, M. d. C. G. (2010). A influência da intensidade do exercício físico aeróbio no processo aterosclerótico. Revista Brasileira de Medicina do Esporte, 16, 382-387.

Wei, M., Gaskill, S. P., Haffner, S. M., Stern, M. P. (2012). Waist Circumference as the Best Predictor of Noninsulin Dependent Diabetes Mellitus (NIDDM) Compared to Body Mass Index, Waist/hip Ratio and Other Anthropometric Measurements in Mexican Americans-A 7-Year Prospective Study. Obesity research, 5(1), 16-23.

World Health Organization. Global Strategy on Strategy on Diet, Physical Activity and Health. Geneva: World Health Organization; 2004.

Zhu et al. (2012). Combination of BMI and waist circumference for identifying cardiovascular risk factors in whites. Obesity research, 12(4), 633-645.

\section{Dirigir correspondência a:}

\section{Marcos de Sá Rego Fortes}

Address: Av. João Luiz Alves $\mathrm{S} / \mathrm{N}^{\circ}$ Fortaleza de São João

CEP 22291-090 - Rio de Janeiro - RJ - Brazil

Phone: (21) 2586-2279

E-mail: msrfortes@gmail.com

\section{RECIBIDO: 1-11-2013}

ACEPTADO: 28-12-2013 